NBER WORKING PAPER SERIES

DO TAXES AFFECT CORPORATE FINANCING DECISIONS?

Jeffrey K. Mackie-Mason

Working Paper No. 2632

NATIONAL BUREAU OF ECONOMIC RESEARCH

1050 Massachusetts Avenue

Cambridge, MA 02138

June 1988

This research is part of NBER's research program in Taxation. Any opinions expressed are those of the author not those of the National Bureau of Economic Research. 
NBER Working Paper \#2632

June 1988

\section{DO TAXES AFFECT CORPORATE FINANCING DECISIONS?}

\section{ABSTRACT}

A new empirical method and data set are used to study the effects of tax policy on corporate financing cholces. Clear evidence emerges that non-debt tax shields "crowd out" interest deductibility, thus decreasing the desirability of debt issues at the margin. Previous studies which falled to find tax effects examined debt-equity ratios rather than individual, well-specifled financing choices. This paper also demonstrates the importance of controlling for confounding effects which other papers ignored. Results on other (asymmetric information) effects on financing decisions are also presented.

Jeffrey K. Mackie-Mason Department of Economics University of Michigan

Ann Arbor, MI 48109 


\title{
Do Taxes Affect Corporate Financing Decisions?
}

\author{
Jeffrey K. MacKie-Mason
}

\section{INTRODUCTION}

Nearly everyone believes taxes must be important to financing decisions, but no substantial support has ever been found in empirical analyses. Myers [1984] wrote that "I know of no study clearly demonstrating that a firm's tax statns has predictable, material effects on its debt policy. I think the wait for such a study will be protracted" (p.588). A similar conclusion is reached by Poterba [1986]. Recent stndies which fail to find plausible or significant tax effects include Ang and Peterson [1986], Long and Malitz [1985], Bradley, Jarrell and Kim [1984], Marsh [1982], and Williamson [1981].' This paper disentangles several confounding interactions to provide clear and robust evidence of substantial tax effects. The probability that a firm will issue debt to raise new funds decreases as the expected value of interest deductibility declines.

The paper uses a different empirical method and data set from previous studies. I study the observable, incremental financing choices made by firms; previous researchers look at a firm's debtequity ratio. The leverage ratio approach is subject to simultaneous equations bias, misspecification of the choice model, and dynamic misspecification. The incremental choice approach overcomes most of these problems.

I construct a sample of financing decisions from a data source not previously utilized to stndy capital structure decisions: new public-issue security registrations with the SEC. The sample constains 1418 observations from 1977-1984, covering new registrations for 613 different firms. The large size of the data set and the focus on well-defined individual decisiosn allows me to control for many more factors than has been possible in previous studies.

The results provide some of the first clear evidence that tax policy does significantly affect financing decisions. The higher are a firm's non-debt tax shields (e.g., investment tax credits, tax loss carryforwards), the less likely it is to issue debt at the margin, because expected tax shield

I would tike to thank Alan Auerbach, Rob Gertner, Roger Gordon, Jerry Hausman, Paul Bealy, Jeff Miron, Myron Scholes, Greg Niehaus, Bob Pindyck, Jim Poterba, Jay Ritter, Nejal Seyhun, Glen Sueyoshi, and seminar audiences al MIT, Michigan and NBER for helpful comments and advice. Donna Lawson and Sue Majewski provided superb research assistance, with support from a Rackham Research Grant. The first version of this paper was prepared with financial support from the Alfred P. Sloan Foundation.

1 One exception is Bartholdy, FIsher and Mintz [1987], which does not find convincing non-debe tax shield effects, but uses variation in Canadian corporate tax rates to identify significant interest deductitility effects. 
"crowding out" lowers the value of interest deductibility. Evidence is provided which indicates that previous studies may have failed to confirm the tax shield effect because they did not control for confounding effects.

The next section describes the main themes of tax-related and other theories of financing decisions. Section 3 discusses the empirical method, and contrasts it with prior research. Section 4 presents the empirical analysis. This begins with a description of the testable implications of theory and the data employed, followed by the results, specification and robustness tests, prediction tests, and calculations of the economic magnitudes of the results. Sample selection and data construction details are provided in an appendix.

\section{GENERAL HYPOTHESES}

In recent years there have been many new theoretical treatments of capital structure decisions. I first summarize tax-based theories of financing decisions, and present testable implications. In order to test the tax storjes, however, it is necessary to control for any other behavioral effects which may interact or be correlated with the tax effects. Other theories are presented in Section 2.2.

\subsection{Taxes and Financing}

Taxes are hypothesized to enter a firm's leverage decision calculus. ${ }^{2}$ An optimal leverage theory describes supply and demand functions for debt in a competitive capital market which clears in equilibrium. The benefits and costs of outstanding debt determine the firm's debt supply function; the benefits and costs of holding debt determine the market demand. The firm's optimal debt level is determined as the market-clearing equilibrium quantity. Taxes may provide benefits or costs for both suppliers and demanders of financial instruments.

Miller [1977] inspired the most recent theories of optimal leverage by setting the firm's debtlevel decision in an equilibrium supply and demand framework to investigate the effects of taxes. Letting the personal tax rate on equity be zero, individuals will be indifferent between holding debt and equity if $r_{e}=r_{d}\left(1-r_{p d}\right)$, where the subscripts $(d, e)$ distinguish between the risk-adjusted returns to equity and debt, and $r_{p d}$ is the personal $\operatorname{tax}$ rate on debt. ${ }^{3}$ In terms of bond prices, $P_{d}=\frac{1}{r_{d}}$, personal taxes imply a downward sloping demand curve; to induce investors to hold larger

\footnotetext{
2 I nee the term "leverage" because of its common ase in the literature. With more than two securities, an optimal capital structure is a set of optimal security/asets ration.

3 The readts go through as long as the persoad tax rate on debt is greater than that on equity.
} 
quantities of bonds, price must fall because marginal investors will be those with increasingly high tax rates on the return to debt (see Figure 1).

On the supply side the tax deductibility of interest payments, but not payments to equity, subsidizes corporate borrowi g. Payments to security holders cost either $r_{e}$ or $r_{d}\left(1-\tau_{c}\right)$, where $\tau_{c}$ is the corporate tax rate. Indifference between selling bonds and issuing equity requires $P_{d}=$ $P_{e}\left(1-\tau_{c}\right)$. If all firms face the same corporate tax rate, the supply curve for bonds is perfectly horizontal (curve $S_{M}$ in Figure 1). As with Modigliani and Miller's [1958] Proposition I, leverage is irrelevant to firm value, although in aggregate an optimal debt-equity ratio exists for the economy, determined by bond market equilibrium.

More recent papers have discussed other tax-related supply-side costs of borrowing. Interest deductibility has current value only if the firm is paying positive taxes. In an uncertain world, the higher are other tax shields, the greater is the probability that the firm will find itself in a non-tax status; hence the lower the expected value of the interest deduction (DeAngelo and Masulis [1980]; Ross [1985]).

In general, the marginal tax rate on interest deductions may be decreasing in the level of debt outstanding: $\tau_{c}=\tau_{c}(B), \quad \tau_{c}^{\prime}<0$, where $B$ represents bonds outstanding. The margin between borrowing and issuing equity is determined by $r_{e}=r_{d}\left[1-\tau_{i}(B)\right]{ }^{4}$ The resulting supply curve is given by $P_{d}=P_{e}\left[1-\tau_{c}(B)\right]$. The supply price of debt is increasing in the debt level of the firm, so the firm in general has an optimal interior leverage ratio.

The supply curve slopes upward since leverage increases the expected after-tax cost of borrowing $\left(\tau_{c}^{\prime}(B)<0\right)$. One implication of the model is that the firm's propensity to issue debt (rather than equity) will increase as its marginal tax rate increases. However, statutory marginal tax rates on U.S. corporations have varied little in the modern economy, and effective marginal tax rates are nearly impossible to measure without access to confidential corporate tax returns. ${ }^{5}$ Another implication is that the higher are a firm's available non-debt tax shields, the less likely it will be to issue debt. This prediction will be tested in the empirical analysis using a number of different publicly available measures of expected tax shield capacity.

The leverage theory also predicts that the firm's optimal debt ratio depends on the location of the market demand curve for bonds. If arbitrage ensures that a single risk-adjusted interest rate

\footnotetext{
4 The notation is heuristic; I am ignoring, for instance, the proper treatment of mathematical expectation when functions are nonlinear in the stochastic variables.

5 Bartholdy, Fisher and Mintz [1987] test this implication for firms in Canada, where statutory tax rates have fluctuated.
} 
is offered, then each firm faces the same market (risk-adjusted) demand curve. However, different shareholder clienteles may form based on the dividend payout rate, since variation in personal tax rates affects the desirability of receiving equity returns in the form of dividends rather than capital gains. Desired debt-ratios may vary with clientele, if high-tax-rate investors prefer to borrow on their own account to obtain interest deductions at their personal tax rate, rather than the lower corporate tax rate (Auerbach [1983]; Auerbach and King (1985]). Estimated clientele tax rates are used to test this hypothesis.

To summarize, the testable implications are that variations in the expected tax deductibility of a marginal dollar of interest will negatively affect the issuance of debt, as will the personal tax rate on the marginal purchaser of the firm's equity.

\subsection{Other Factors}

Costs of Leverage. Non-tax leverage-related costs of borrowing may enter the firm's debt supply decision. In order to consistently estimate the effect of taxes on financing, other explanatory variables must be controlled for in the statistical analysis. A conclusion reached below is that ignoring such controls may be one reason that prior research has not uncovered substantial tax effects.

I will refer to all non-tax related costs of leverage as costs of financial distress. Extending the supply curve analysis above, equilibriurn requires $r_{e}=r_{d}\left[1-\tau_{c}(B)\right]+\Delta(B)$, where $\Delta(B)$ represents financial distress costs, and $\Delta^{\prime}>0$. The supply curve is then $P_{\mathrm{d}}=P_{\mathrm{e}}\left[1-\tau_{c}(B)\right] \times \frac{r_{e}}{r_{e}-\Delta(\theta)}$ (see supply curve $S^{*}$ in Figure 1).

Traditionally, real wealth costs of bankruptcy have been seen as a deterrent to firms seeking high debt ratios. ${ }^{6}$ Further, if financial decisions reflect the concerns of management as well as owners then the costs of bankruptcy as perceived by the financial decisionmaker may be quite high. ${ }^{7}$

Many other conflicts between managers and shareholders (known as principal-agent problems) have dominated the recent literature on financing decisions. If increasing debt raises increases the probability of costly interest conflicts occurring, then rational investors will discount the value of that debt, thereby raising the costs of borrowing to the firm.

\footnotetext{
6 See, e.g., Milker and Modigliani [1963]. Recent evidence suggests that expected bankruptcy costs may be significant (Altman [1984]).

7 Management couts of bankruptcy may be higher due to fixed human capital inveatment. See, e.g., Donaldson $[1969,1984]$, for the view that financial decisions primarily reflect self-interesied managerial objectives.
} 
Myers [1977] and MacKie-Mason [1986a] examine a conflict over investment decisions which outstanding debt may induce. Management will commit new resources to a project only if the expected return is sufficient to pay off the outstanding debt liabilities, as well as earn an acceptable return on the new investment costs, if the alternative is low-cost default. Since the first-best is to go ahead if the expected payoffs are sufficient to earn a return on the incremental costs, underinvestment results, which raises the equilibrium cost of borrowing.

Jensen and Meckling [1976] suggest that firms with high debt levels and limited liability will have an incentive to take on excessively risky projects. Risky projects with limited liability offer a call option to shareholders: high payoffs in good states, zero payoff in bad states. Taking on a risky project when debt is high can transfer wealth from bondholders to shareholders. Other costs of financial distress associated with borrowing include contracting, bonding and monitoring costs necessary to ameliorate both operating and investment decision agency problems (Jensen and Meckling [1976]); and unfavorable terms of trade with customers, workers and suppliers due to distorted liquidation incentives (Titman [1984]). ${ }^{8}$

Financing Hierarchy. A fundamentally different view of financing decisions holds that firms have hierarchical preferences over marginal sources of funds, and only choose sources low on the hierarchy when they face credit constraints for preferred sources. This "pecking order" theory predicts that firms always prefer to use internal funds as the marginal source of finance; if that is not possible, they employ debt; and only if debt is unavailable do they issue new shares. The hierarchy story needs two elements: conditions which lead firms to have hierarchical preferences, and reasons why preferred sources are sometimes unavailable, since we see all types of financing. A general empirical investigation should allow for the possibility that some firms are at corner solutions for optimal marginal financing decisions.

Hierarchical preferences typically arise in signaling models. Leland and Pyle [197i] suggested a similarity between the market for new shares and the "lemons" model of used car sales. If managers - seek to maximize the wealth of current shareholders when managers have private information about future firm value, then stock will be issued only when there is "bad news"; i.e., when managers believe the market will overprice the issue, transferring wealth from new to old shareholders. In equilibrium, investors believe that an equity issue is a signal of bad news, which lowers the price of equity. Myers and Majluf [1984] present a model in which debt issues are always preferred

8 Another supply curve effect may be the cost of controlling managers' use of "free cash flows." Jensen [1986] argued managers may use uncommitted funds to further their own objectives, and thus that firms with free cash are more likely to jssue debt than equity, because interest repayment restricts the managers' discretion over the uses of cash. 
to equity because of the hidden information problem; Bagnoli and Khanna [198i] generalize the Myers-Majluf model to include borrowing costs (such as costs of financial distress) so that equity issues are sometimes preferred. ${ }^{9}$

Several recent theoretical models have predicted credit rationing, which could explain why firms sometimes issue equity if they always prefer debt. The basic result emerges for debt when an increase in the interest rate decreases the expected return on a loan which can happen, for instance, when firms know more about the riskiness of their future investments than do banks (Stiglitz and Weiss [1981]). Gale and Hellwig [1985] and Williamson [1987] obtain credit rationing in models with unobserved ex post information and monitoring costs rather than ex ante hidden information.

At present, there seem to be few implications of credit-rationing models which are testable in a study of individual firm security offerings. I control for suspected factors, but do not try to confirm or reject specific hierarchy predictions. ${ }^{10}$

\section{Method}

The tests for the effects of tax policy on financing are carried out in a general analysis of the firm's capital structure changes. This section discusses problems with the usual approach to capital structure decisions, and describes the alternative method employed in this paper.

\subsection{Analyzing Debt-Equity Ratios}

Most empirical studies assume that the firm's capital structure is in equilibrium, and estimate the determinants of the debt/assets ratio." ${ }^{11}$ There are at least two difficulties with the empirical implementation of this approach: first, the firm's optimal capital structure policy is only part of the simultaneous system of firm decision-making functions. Second, the decision problem bas a dynamic structure. I shall discuss these problems and then describe the incremental choice analysis which I employ as an alternative to analyzing debt/assets ratios.

The simultaneity of uses and financing decisions is potentially important. ${ }^{12}$ Nearly all of the

\footnotetext{
9 Conntantinides and Grundy [1986] study the role of share repurchases as a signaling device.

10 Part of the difficulty in observing clea indications of credit rationing is that the empirical analysis is limited to a homogeneons class of security offeringa: public issues. Credit rationing models emphasize internal versus external financing, and provide tese plansible explanations for observing equity rather than debt in public issues.

11 Studie which adopt this approech include Auerbach [1985]; Bartholdy, Fisher and Mintz [1987]; Bradley, Jarrell and Kim [1984); Long and Malitz [1985); Ang and Peterson (1986]; and Wiltiamson [1981).

12 See, e.g., Scholes and Wolfoon [1987]. The point is illustrated by Asquith, Brunner and MIullins [1987], who find that the share price effect of takeover announcements varies with the type of financing.
} 
hypotheses described above imply that financial and investment decisions are joint. A firm's optimal leverage ratio should depend on whether it is growing or declining, and on the details of its investment and operating decisions. However, the disaggregated and simultaneous investment, operating and financing decisions of a firm are difficult to model theoretically, and almost no investment or operating data is available at the level of detail required to empirically analyze the effects of different uses policies on financial policy.

The dynamic structure of the firm's optimization problem also poses difficulties for an analysis of financing decisions. Capital structure changes are lumpy, and relatively infrequent, rather than daily, as continuous response to stock price changes, inflation, and other unexpected economic events would require. Measuring the current debt/assets ratio will typically yield an out-of-equilibrium ratio, not the desired optimum. ${ }^{13}$ Nor can measurement errors be assumed to average out: if credit was rationed when firms wanted to raise new debt financing, observed debt/assets ratios will be systematically below optimal, and estimates of leverage determinants will be biased.

An alternative approach to the dynamic problem has been to estimate the determinants of longrun debt levels, measured as several-year averages. ${ }^{14}$ But, if the hierarchy model is sometimes the correct description of optimal financial decisions, then the firm's debt ratio will be nonstationary and path-dependent. Two firms which appear identical to the econometrician will likely have, and should have, quite different debt ratios depending on their characteristics and market expectations at the particular times when they actually raised new finance. ${ }^{15}$

As another criticism of debt/assets ratio studies, Gordon [1985] points out that researchers invariably seek to control for scale differences across firms by measuring explanatory variables as ratios, usually with respect to a measure of assets. Thus, assets appear both in the dependent (debt-asset ratio) and the explanatory variables, leading to coefficient estimates which are biased and inconsistent.

\footnotetext{
13 To my knowledge, only Auerbach [1985] has explicitly modeled an adjustment process, by arbitrarily imposing the Koyck, or geometric lag structure.

14 See, e.g., Bradley, Jarrell and Kim [1984].

15 Myers [1984] snggests that path-dependency is an important reason why the $R^{2}$ of debt/assets ratio studies is usually quite low. Evolntion in the simultareous determinants of investment and financing in an optimal leverage model would also yield non-stationarity.
} 


\subsection{Incremental Choice Approach}

I adopt an approach which ameliorates some of the problems discussed above, although they cannot be solved entirely. I look at a set of actuai, observable individual decisions that firms make: the choice between debt and equity, conditional on the firm raising new capital with a public issue. ${ }^{16}$ The anaiysis yields consistent (conditional) estimates of the choice between equity and debt.

This approach has two advantages in reducing the bias from ignoring the simultaneity of financial and investment decisions. First, investment policy is partially controlled by restricting the sample to homogeneous decisions; namely, only new public issues. This should reduce variation in uses policy by focusing on instances in which the firm is taking on new investments and expanding its asset base.

Second, investment policy is further controlled by investigating only the choice between types of securities, rather than the amount of the change in security supplies. ${ }^{1 i}$ This should lead to clearer, more powerful results by asking a more narrowly defined question: if a firm has already decided to raise new funds from the public, will it issue stock or bonds?

Having observations only on a subset of financing options-viz.. public debt and equity-raises interesting econometric issues. To obtain from this data consistent, unconditional estimates of the determinants of the probability of a public debt issue relative to an equity issue, financial decision making must be a nested process. One possibility is illustrated in Figure 2. First the firm determines whether to increase, decrease or leave unchanged its total available funds. If funds are to be increased, then the choice between private sources and public is made. If the firm decides to go public, then it decides whether to issue bonds or shares. In this scheme, estimating the public debt-equity choice in isolation is appropriate. ${ }^{18}$ The nested model assumes weak substitutability between aiternatives on different branches; e.g., that public debt and equity are more substitutable than are, say, public stock issues and bank debt.

The nested decision-making model may not be appropriate (or the true nesting may not isolate public issues in their own branch). In that case, unconditional consistent estimates of the

\footnotetext{
16 A few other papers use a similar statistical approach. Marsh [1982] uses older, British data, and ignores any tax effects. Taub [1975], Baxter and Cragg [1970], and Martin and Scott [1974] are primarily classification studies; they test essentially none of the modern capital structure by potheses.

17 With lumpiness in security issues, a major expansion decision may lead to 2 big change in the debt/assets ratio, even if the optimal ratio hasn't changed.

18 McFadden [1981] discuses the utility theory anderlying a nested preference model of this sort. Terminal branches of the tree, such as the public issue branch of Figure 2, can be consistently estimated with standard discrete choice methods, such as the probit technique employed below.
} 
probability of a public debt (or equity) issue require specification and estimation of the full set of simultaneous financing choices (including retained earnings, bank debt, etc.). However, conditional on a firm issuing either debt or equity, the approach with a limited choice menu still yields consistent results for the relative (among the observed choices) issue probability. Suppose the financing choice is in fact made between public debt and equity, and bank debt, simultaneously with the investment policy. The system of simultaneous supply equations for the three sources of finance can be transformed to a reduced form for the choice of debt or equity conditional on going public. The reduced form works because the random utility model implies that, if the firm does issue publicly, a necessary and sufficient condition for optimality is that its chosen instrument, say debt, yield a higher value of the objective function than the other public alternative, equity.

By focusing on the incremental choices made by firms, problems of specifying the structure of the dynamic adjustment process are also avoided. We are interested in the direction of change, and need not know how far away the firm is from any target. Further, the incremental choice approach yields a test of the optimal capital structure hypothesis against the hierarchy story, essentially by looking for mean reversion in debt/asset ratios.

\section{EMPIRICAL ANALYSIS}

\subsection{Data}

A sample of 1418 observations on new, seasoned security offerings was collected from the SEC Registered Offerings Statistics tape. Table 2 reports issue statistics for the universe of all primary public offerings ${ }^{19}$ and the sample used in most of the econometric analysis. Based on the number of debt and equity issues, and the amount of money raised, the sample seems reasonably representative. Details on sample selection and variable construction are given in the appendix.

Convertible and straight debt are classified as debt; preferred, convertible preferred and common stock are classified as equity. Although a multinomial analysis for the several different security types might be preferable, not enough data are available. In the sample, $98 \%$ of the observations are either straight debt or common stock; no other type accounts for even $1 \%$ of the sample.

Taxes. The primary hypothesis to be tested is whether variations in non-debt tax shields affect the firm's choice to finance with debt or equity, by lowering the expected value of taxable interest deductions. A number of variables relevant to this hypothesis are available for firms in our

\footnotetext{
19 The universe includes initial public offering* and anit offerings (e.g., simultaneous offerings of more than one
} security type), which are excluded from the estimation sample. 
sample. ${ }^{20}$ Data were collected from the COMPUSTAT tapes, with missing values filled in where possible from Moody's Industrial Manual and individual corporate 10-K reports.

The primary non-debt tax shield variables are investment tax credits (ITC), research and development (R\&D), and advertising. The latter two are tax shields because they are immediately expensed for tax purposes, but represent investments in assets which yield value over several years. I also use the firm's book tax loss carryforwards, which have the same effect as shields in lowering expected interest deductions. ${ }^{21}$

Various measures of depreciation are available, but measurement problems are severe. Book depreciation has no relation to depreciation deductions actually claimed in a given tax year, or expected over the next few years (when crowding out of new interest deductions is possible). An alternative measure is deferred taxes, which represent differences between actual tax payments and book tax liability due to timing differences. ${ }^{22}$

I am able to calculate the actual cash flow of taxes paid during a year from balance sheet entries. This is not the same as the firm's actual tax liability during the year; early and late payments, differences between fiscal and tax years, adjustments for loss carrybacks and so forth can completely undo the relationship. A clientele tax rate (the implicit rate on the marginal purchaser of a firm's equity) is estimated from ex-dividend day stock price behavior following Auerbach [1983].

Other Factors. Controls for asymmetric information (moral hazard and signaling) effects are employed in the analysis. I briefly describe these variables here; details are provided in the appendix. In nearly every case, the variables were chosen to conform with empirical studies of capital structure decisions which emphasized asymmetric information hypotheses. ${ }^{23}$

Moral hazard hypotheses emphasize the divergence between the interests of managers and owners (or others) when a firm is near financial distress or bankruptcy. I consider a number of indicators of the likelihood of bankruptcy, including the firm's systematic and unsystematic operating risk (unlevered "beta" and "sigma"), and two different measures of the volatility of accounting earnings (VEARNA and VEARNB).

20 Unfortunavely, nearly all of them are “book" measures; that is, they are the numbers reported on the accounting books, rather than components of actual tax liability. Careful at tempts, such as in Auerbach [1985], to converi accounting number to actnal cash fows do not seem to have succeeded in adding much explanatory power to debt/asset ratio analyses. See also the discusion of tax loss carry forwards in the appendix.

21 Tax variables were scaled by net sales, to measure a fraction of shielded revenue.

22 A major portion of deferred taxes is usually due to accelerated depreciation deductions, although many timing differences contribnte, not all of which are tax shields.

23 See, e.g., the stodies ciled in note 0 , and also Marsh [1982]. 
Financial analysts look at a number of accounting ratios when they evaluate a firm's prospects. As another indicator of financial distress, I constructed Altman's [1968] ZPROB predictor of bankruptcy. Altman's multiple discriminant function correctly classified $94 \%$ of the firms that went bankrupt in the next year, and $97 \%$ of those that did not. Since nearly every finance textbook presents ZPROB as a predictor of bankruptcy likelihood, this may be a good measure of the type of information managers use when evaluating the expected financial distress costs of security issues. $^{24}$

The exercise of future growth opportunities and invest ment options are decisions which are difficult to fully control through specification in contracts between investors and managers. Following Myers [1977], the costs of moral hazard are expected to be related to the fraction of firm value which is accounted for by intangible, discretionary opportunities. The fraction of a firm's net book assets accounted for by net plant and equipment (FPLANT) is a (negative) indicator of discretionary opportunities. ${ }^{25}$ Long and Malitz [1985], and Bradley, Jarrell and Kim [1984] suggest that expenditures on advertising and on research and development are indicators of intangible growth opportunities. ${ }^{26}$

To test Jensen's [1986] free-cash-flow hypothesis, I construct a cash-flow deficit variable first defined by Auerbach [1985], which represents cash deficit after committed expenditures. Potential ownership dilution is measured by dividing the value of an issue by the market value of equity. Ownership dilution may exacerbate moral hazard problems through reduction in shareholder monitoring (the free-rider problem). ${ }^{27}$

The "hierarchy" theory of financing decisions, in contrast to "optimal leverage" theories, asserts that the firm has no optimal leverage ration, and thus predicts that desired marginal sources of funds are independent of the firm's actual debt-assets ratio. To test the strong version of this hypothesis, the current and long-run debt/assets ratios are entered separately and differenced.

\footnotetext{
24 See, e.g., Brealey and Myers [1984], p. 646. The function is retested in Altman, Haldeman and Narayanan $[197 \%]$.

25 Myers [1977] suggests that managers may rely on book assets and liabilities when making financial decisions because book value is a better measure of fixed, or nondiscretionary value. Market values include the value of discretionary uses of assets.

26 Note that we cannot distinguish between tax and moral hazard stories with these variables.

27 This variable may be endogenous, to the extent that investment decisions and financing decisions are simultaneous. Existing empirical evidence does not convincingly demonstrate the extent to which choice of financing instrument affects the proportionate size of an issue. I estimnte both with and without the variable because it provides eubstantial explanatory power without seeming to affect other coefficients dramatically.
} 
The strength of hierarchical financing preferences may depend on how costly the differences between managers' and investors information can be in different situations. One suggested measure for the potential cost of asymmetric information is the standard deviation of first differences in accounting earnings, VEARNA (MacKie-Mason [1986b]; Dierkens [1986]). This is the forecast error for earnings prediction by investors if (as the accounting literature has found) ${ }^{\mathbf{2 8}}$ earnings follow a random walk. ${ }^{29}$

It is also possible that the dilution variable is an indicator of signaling costs, since greater dilution provides a greater opportunity for transferring wealth from new investors to current shareholders. The resulting stock price drop may be larger. Further, to the extent that managers' compensation is tied to stock prices (through stock options and other incentive schemes) there may be strong motivation to avoid large price drops. This story might explain why stock issues are more frequent, but smaller in value than debt issues (see Table 2).

Other Controls. Industry dummy variables are entered to control for various fixed effects which might be present. One such effect might be inter-industry variation in the degree of hidden information. I also estimate year dummies to capture any unobserved system-wide effects, such as changes in tax policy or other general economic conditions, and enter net assets to control for any size effects.

The predicted effects of the explanatory variables under the major hypotheses are summarized in Table 1. Sample descriptive statistics are reported in Table 3.

Two further notes about the data are in order. First (except when indicated in Section 5) I used data from the year prior to the year in which a new issue was registered, to avoid problems with endogeneity. ${ }^{30}$ Second, the theories predict that the net benefits of choosing a particular security type arise from expectations about the future. ${ }^{31}$ I use observed values as the information set on which expectations are based; I consider the use of more historical data in Section 5.3.

\footnotetext{
28 See Healy and Pelapu [1986] and Watts and Zimmerman [1986], ch. 6 for summaries of the relevant studies.

29 Note that VEARNA is also a control for volatility under the financial distress hypothesis.

30 I estimated some versions of the model using contemporaneous data, with expected results: clearly endogenous variables dominated, with other variables moving substantially closer to zero and becoming insignificant.

31 For instance, the value of future interest deductions on a new debt issue depend primarily on future tax shields. See, however, Altshuler and Auerbach [1986] for time-dependence due to loss and credit carryforwards.
} 


\subsection{Econometric Model}

Conditional on the firm raising new funds from the public, a necessary and sufficient condition is that it choose to issue the security which contributes the most to the decisionmaker's objective function. Let the increment to the value function from alternative $i, i \in\{$ debt,equity , be

$$
\begin{aligned}
V_{i} & =x_{i}^{\prime} \beta_{i}+\epsilon_{i} \\
\epsilon & \sim \mathcal{N}(0, \Sigma)
\end{aligned}
$$

where $x_{i}$ is a $K$-vector of choice characteristics and firm attributes, $\beta ;$ a $K$-vector of parameters to be estimated, and $\epsilon$ a $C$-vector of unobservable disturbances following a multivariate normal distribution, where $C$ is the number of choices available.

The firm's choice, $i^{*}$, is observed, but not the realization of the incremental value of the choice, $V_{i} \sim$. Let

$$
y_{i}= \begin{cases}1, & \text { if } V_{i}=\max \left\{V_{1}, V_{2}\right\} \\ 0, & \text { otherwise }\end{cases}
$$

The econometric problem is to estimate the $\beta_{i}$ given $N$ observations of debt or equity issues and the characteristics vector $\left(y_{i}, x_{i}\right)$. The probability model is

$$
\begin{aligned}
\operatorname{Pr}\left(y_{i}=1 \mid x\right) & =\operatorname{Pr}\left(V_{1}>V_{2}\right) \\
& =\operatorname{Pr}\left(\epsilon_{2}-\epsilon_{1}<x^{\prime} \beta\right)
\end{aligned}
$$

where $x \equiv x_{1}-x_{2}$, and the parameter vector $\beta$ is assumed to be identical across choices. Using the properties of the multivariate normal, define $\epsilon \equiv \epsilon_{2}-\epsilon_{1} \sim \mathcal{N}\left(0, \sigma^{2}\right)$, where $\sigma^{2}=\sigma_{1}^{2}+\sigma_{2}^{2}+2 \sigma_{12}$. Then, for observations $n=1, \ldots, N$,

$$
\operatorname{Pr}\left(y_{1 n}=1 \mid x\right)=\int_{-\infty}^{x_{n}^{\prime} \beta} \frac{1}{\sqrt{2 \pi} \sigma} \exp \left[-\frac{1}{2}\left(\frac{\epsilon}{\sigma}\right)^{2}\right] d \epsilon=\Phi\left(\frac{x_{n}^{\prime} \beta}{\sigma}\right)
$$

I obtain estimates, $\hat{\beta}$, by maximizing the log of the likelihood function for the sample. ${ }^{32}$

\footnotetext{
32 Since the likelihood function is globally concave, the estimates of $\beta$ are unique, if bounded.
} 


\subsection{Results.}

The main results are presented in Table 4. Column 1 includes most of the tax variables and controls described above. Column 2 excludes a few variables which had no explanatory power, but adds 16 industry dummy variables (the estimated dummy coefficients are reported in Table 5).

Taxes. The central hypothesis is that by crowding out interest deductions, tax shields discourage debt. Tax loss carryforwards (TLCF) and investment tax credits claimed (ITC) are the tax shield measures which appear to contain the most information for financing choices. It has been typical in previous (leverage ratio) studies for the coefficient on various tax shields to be positive, contrary to expectations. ${ }^{33}$ Other authors have suggested that since high ITC occurs when a firm makes large investments in equipment, the result may indicate an increase in the firm's debt capacity when tangible, easily re-sold capital is a large fraction of firm assets, consistent with the moral hazard hypothesis.

An innovation in this paper is the attempt to disentangle the two roles of ITC-as an indicator of tax shields, and of tangible assets-so that we may determine the effect of tax policy after controlling for firm characteristics. Since tax shield effect is to crowd out interest tax deductions, the effect of tax shields should be greater the more likely it is that the firm will a zero-tax status. I interact an indicator of financial distress to obtain the desired effect: ITC alone will be correlated with the level of tangible capital equipment (regardless of expected tax status), while ITC interacted with a financial distress indicator will measure the potential for "crowding out" of tax savings.

I use ZPROB as an indicator of financial distress. The results in column 1 include ZPROB individually, and interacted with ITC and VEARNA. ${ }^{34}$ The coefficients on ITC are striking, and as predicted: ITC by itself is positive and significant, as the moral hazard hypothesis suggests, but ITC/ZPROB is negative and significant, as predicted by the tax shields story.

Tax loss carryforward (TLCF) also has a negative and significant coefficient, indicating a decreased likelihood of debt issue when interest deductions may not be usable. ${ }^{35}$

The clientele tax rate has no significant effect, consistent with Auerbach's [1985] results. I also estimated specifications (not presented here) with book depreciation, deferred taxes, and taxes paid, as well as these terms interacted both with ZPROB, and with VEARNB (one of the earnings

33 See, for example, Bradley, Jarrell and Kim [1984]; Auerbach [1985], and Ang and Peterson [1986].

34 A low ZPROB indicates a high probability of bankruptcy. To ease interpretation, I use its inverse.

35 See the appendix for discussion of problems with using the TLCF variable in COMPUSTAT for studying tax policy effects. 
variance measures, and another potential indicator of financial distress). These variables, all of which are measured with substantial error relative to the desired definitions, always have the predicted signs, but enter insignificantly, and without important effects on the other estimated coefficients. Thus, they do not contradict the role of taxes, but offer no more than weak support for the hypothesis.

Column 2 contains the coefficients when the industry dummies are included. This specification controls for industry-specific effects, which could have been correlated with the various tax variables, leading to spurious results. However, the magnitudes of the TLCF and ITC coefficients are statistically unchanged, and the estimates for the ITC variables are still quite precise.

The results in Table 4 provide some of the first clear empirical evidence that taxes affect financing decisions at the margin. Previous studies have not only been unable to demonstrate a negative effect of tax shields on debt financing, but have in fact estimated unexplained, significant positive effects. Table 6 presents evidence that the absence of controls for confounding effects in previous work may explain the difference between those results and mine.

Table 6 presents a specification identical to column 1 in Table 4, except that the interactions with the financial distress indicator (ZPROB) are omitted. The coefficient on ITC is now positive but insignificant, and the coefficient on TLCF is smaller and less significant. The importance of separating the two roles of ITC is dramatically clear from comparing the results of the two specifications.

The fact that TLCF has explanatory in my analysis when it has not elsewhere may be due to two factors. First, current TLCF may not be very important if a firm is trying to attain a long-run debt/asset ratio, as is presumed by most other stories; the tax shield effect may be transitory. Second, in other specifications (not reported here) I have found that the significance of TLCF is sensitive to the inclusion of the stock price change variable. TLCF as a tax shield is likely to be confounded by its role as an indicator of poor firm performance (Bagnoli and Khanna [1987] suggest that market timing may encourage debt when performance is poor). $\Delta P$ incorporates the market valuation of the firm's performance during the year; what remains in TLCF is a measure of future crowding out of interest deductions.

To summarize, when firms are relatively likely to be in a no-tax status, high tax shields are associated with a strong and significant decrease in the probability that a firm will choose to issue debt. The plausible and significant results obtained, where others have failed, may follow from controlling for more confounding effects; in particular, the correlation of ITC with tangible capital which diminishes the costs of moral hazard, and the correlation of TLCF with firm performance. 
Other tax variables appear to be measured with too much error to obtain statistically significant estimates of their eflects.

Other Factors. The numerous controls used in the analysis provide information on the importance of other theories of corporate financing preferences. I summarize some of the main findings Irom Table 4 here; a more detailed discussion can be found in MacKie-Mason [1986b].

A number of risk measures control for the proposition that greater risk of financial distress discourages debt issuance, usually associated with the role of bankruptcy and other financial distress costs. However, the tax shield hypothesis makes the same prediction (given a level of non-debt tax shields, interest deductibility is expected to be worth less, the more likely is the firm to enter zero-tax status).

"Beta" and "sigma", the estimates of systematic and firm-specific risk from the market model regressions, both have the predicted negative sign but no explanatory power. The coefficients on both earnings varjance measures (VEARNA and VEARNB) have the predicted sign and are quite precisely estimated. Collectively, these estimates are consistent with both the moral hazard and tax hypotheses.

The strongly significant and positjve coefficient on the firm's tangible capital intensity (FPLANT) appears to be strong evidence supporting Myers's [1977] conjecture that debt issuance is supported by "bonding" (against moral hazard) in the form of tangible assets. (This result also supports the interpretation of ITC as an indicator of tangible assets, emphasizing the importance of controlling with ZPROB.)

No evidence emerges on Jensen's [1986] "free cash flow" hypothesis; the coefficient is imprecisely estimated. Advertising and R\&D both enter significantly with a positjve sign. These results are contrary to both the tax and moral hazard predictions. ${ }^{36}$ A different interpretation for R\&D is conjectured below.

The current debt/assets ratio has a small, but not very significant effect. On the other hand, the change in leverage (measured as the current ratio minus the ten-year mean) enters with a strongly significant negative coefficient. This evidence of mean reversion suggests that firms have some tendency to ajm for optimal long-run leverage ratios, rejecting the strong hierarchy claim that incremental choices will jgnore the leverage ratio.

\footnotetext{
36 Long and Malits [1985] and Bradley, Jarrell and Kim [1984] obtajned negative signs in their debt/assets ratio studies. However, their papere entimate sparse regreassions, focusing on the moral hazard hypothesis. The evidence above on the importance of taxell, and of controlling for confonnding effects, throws doubt on the validity of their results.
} 
Other indicators for a financing hierarchy provide mixed evidence. VEARNA was suggested as a (positive) indicator of information asymmetries; it has a negative coefficient, however. The positive coefficient on VEARNA/ZPROB indicates that when the probability of financial distress is especially high (low ZPRO! and volatile earnings), the firm issues debt; neither moral hazard nor signaling stories provide an obvious explanation for this resuit.

Another possible indicator of an asymmetric information-induced financing hierarchy is the positive coefficient on R\&D: the more research a firm does, the greater the opportunities for a divergence between insider and outsider information. The evidence is strengthened when industry dummies are added; however the interpretation is an $e x$ post rationalization, and the coefficient is somewhat unstable in other specifications.

The important ownership dilution effect may be due in part to the signaling problem, as well as to the value of control, if big issues lead to unusually large drops in stock price. An issue value effect on stock price drops has been previously rejected by Marsh [1979] and Hess and Frost [1982], but was supported by Asquith and Mullins's [1986] study of announcement date (rather than issue date) price effects. The estimated sign on dilution is consistent with this notion, but cannot distinguish between the signaling and moral hazard hypotheses.

The same market timing phenomenon as found by other researchers is supported by the analysis: firms are more likely to issue equity when their stock price is up $\left(\Delta P<0\right.$ and very significant) ${ }^{37}$

Summary Statistics and Specification Analysis. The summary goodness-of-fit statistics for the model are quite good for a discrete choice analysis of the behavior of many diverse firms over several years. The $\rho^{2}$ statistic indicates the percentage of the minimum possible likelihood value we are able to explain with the model, and thus is analogous to the $R^{2}$ measure from a minimum-distance estimator. $\vec{\rho}^{2}$ involves a correction for degrees of freedom (based on the Akaike Information Criterion), analogous to $\vec{R}^{2}$. The M- $\rho^{2}$ statistic indicates the percentage of likelihood explained by variables other than the constant. A naive forecast of debt-equity issues would predict based on the observed mean ( $24 \%$ debt issues); column 1 is able to improve the likelihood value by $35 \%$ relative to this naive model. ${ }^{38}$

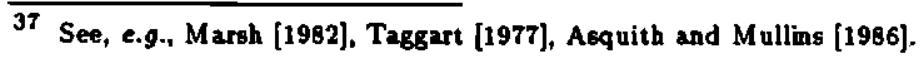

38 The statistics are calculated as: $p^{2}=1-\{l(\dot{\beta}) / l(0)\}$, where $l(\dot{\beta})$ is the value of the likelihood function at the estimated parameter vector, and $l(0)$ is the value if no parameters are estimated; $\dot{\rho}^{2}=1-\{[l(\hat{\beta})-K] / l(0)\}$, where $K$ is the number of parameters estimaled; and $M-p^{2}=1-\{l(\dot{\beta}) / l(c)\}$, where $l(c)$ is the likelihood value if just a constant is estimated. The latter measure was suggested by McFadden [1974]; for a discussion of the first two, see Ben-Akiva and Lerman [1985]. 
Another summary measure is the ability of the model to correctly classify the observed choices in the sample. The estimates in column 1 correctly predict $74 \%$ of the debt issues, and $90 \%$ of the equity issues in the sample, with an overall prediction rate of $86 \%$. By contrast, Marsh [1982] and Martin and Scott [1974] obtain a 75\% correct prediction rate. Marsh calculates a pseudo- $R^{2}$ statistic of 0.37 ; the same statistic for column 1 is $0.48 .^{39}$

A likelihood ratio $\chi_{4}^{2}$ statistic for the four exclusions between column 1 and 2 (without including the industry dummies) is 2.8 , which fails to reject the exclusions at even the $35 \%$ level. ${ }^{40} \mathrm{~A} \chi_{16}^{2}$ likelihood ratio statistic for the industry dummies is 41.4 , which rejects exclusion at the 0.001 level, based on column 2 with and without the industry dummies. 4

As a test of the specification of the model, suppose that optimal security choice depends on the entire history of the firm's characteristics and market conditions. For example, the firm should be choosing its new security based on its expectations of the future; managers may use more than one year of data to form expectations. Alternatively, after reaching an optimal leverage ratio, the characteristics determining the optimum may change, so the value of issuing a particular security type may depend on first differences of the explanatory variables.

The results are in Table 7. I suppose that managers and investors look at two years of data when forming supply and demand decisions for securities. Within this specification we can test for more parsimonious models, such as the model in Table 4, or a model which restricts the coefficients so that first differences in the explanatory variables, rather than levels, are relevant.

Colnmn 1 of Table 7 repeats the specification of Table $4 .^{42}$ Column 2 repeats the analysis using data for the previous two years; column 3 estimates the model with first differences. (Lags are indicated in parentheses.)

Using a likelihood ratio test, the $\chi_{8}^{2}$ statistic for the original model against the expanded specification in colnmn 2 is 10.0 ; we cannot reject the zero restrictions on the second lags at even the $25 \%$ level. The $\chi_{8}^{2}$ statistic for the first-differences specification is 67.0 , so we can reject this version well below the $1 \%$ level. The more parsimonions specification with one year of data does not cost a statistically significant degree of explanatory power, while the first-differences specification is easily rejected.

\footnotetext{
39 The $R^{2}$ is defined as $\left\{1-\exp \left(\frac{2}{N}[(c)-I(\dot{\beta})]\right)\right\} /\left\{1-\exp \left(\frac{3}{S}(c)\right)\right\}$.

40 The results for column 2 withont industry dummies can be found in Mackie-Mason [1986b].

41 The log libelihood without induatry dummies wa -513.0.

42 The eample size is snaller dne to minsing data for variables in other column.
} 
Two interesting specific results emerge in Table 7. First, the first difference in net assets has substantial explanatory power in the model (see columns 2 and 3), i.e., a growing firm is more likely to issue debt. A growing firm may have a greater potential for insiders to obtain information about the firm's prospects that outsiders do not have. These firms might face larger signaling costs for new equity issues, and thus exhibit more hierarchical financing preferences.

The substantial significance increase and the negative sign on the first-differenced cash flow deficit coefficient is also suggestive (column 3). A decrease in the deficit appears to increase the probability of debt issue. This accords with Jensen's [1986] free cash flow hypothesis: firms with an increase in discretionary cash, should issue debt to commit themselves not to use the money on managerial perks, etc.

Prediction. As a further test of robustness, I constructed predictions for a small hold-out sample. "Unit offerings" -registrations for offerings which combined more than one type of securitywere excluded from the estimation sample. There were 61 total securities issued in 35 unit bundles which met the other sample selection criteria. Prediction results for these issues are in Table 8 .

Using the cutoff which minimized the sum of Type I and Type II error in the estimation sample (0.37), I assigned predicted probabilities to debt or equity (using the Table 4 , column 2 coefficients). This yielded $89 \%$ correct predictions, which is actually better than the in-sample classification ( $86 \%$ ). The hold-out sample is small, but this result is quite encouraging because the hold-out sample is more difficult to naively classify than the estimation sample (the debt-equity split is much closer to $50-50$ ).

Many of the unit offerings were bundles of more than one debt type, so the theoretical model which predicts that firms will choose debt or equity may not be inappropriate for the units. However, many unit issues combine debt and equity. Because of this, I also combined units int: agle "pseudo-securities", with the choice between debt and equity measured as the debt fraction of the total issue value. The Spearman rank correlation coefficient between the debt-fraction variable and the predicted probability of issuing debt (for the 35 unit offerings) was 0.42 , indicating that the model does a good job of predicting the "strength" of the debt preferences, as well as the specific outcome.

Economic Importance of Results. Table 9 presents "standardized derivatives" for the major explanatory variables, based on column 1 of Table 4 . The standardized derivative measures the percentage change in the probability of firms choosing debt, given a one standard deviation change in an explanatory variable, evaluated at the sample means of the data. Thus, the results can be 
viewed as predictions of the change in the percentage of issues that would be debt if there was a shift in one of the variables, which is one way to measure the economic magnitude of the results.

Taken individually, the tax shield effects are as economically important as any others except for the ownership dilution effect, and the second earnings variance measure. For instance, a onestandard-deviation increase in ITC/ZPROB is predicted to lower the percentage of debt issues by over 13 points (from about $24 \%$ of issues to $11 \%$ ). Thus, the increase in corporate tax shields during the early 1980 's (e.g., ACRS, safe-harbor leasing, R\&D tax credits, etc.) may in part explain the dramatic decline in the proportion of debt issues (see Table 2). Similarly, the recent (1986) reduction in tax shields (abolishing the ITC and slowing depreciation) may have the opposite effect, although the decrease in the corporate tax rate also makes interest deductibility less valuable. Also, general equilibrium effects must also be considered, as our results demonstrate: decreasing the ITC may reduce the purchase of tangible assets, which will tend to reduce firms' debt capacities.

\section{CONCLUSION}

It is not surprising that no single story can explain all corporate financing decisions. Even restricting the decisions to new public issues, the evidence above clearly demonstrates that managers are concerned with a number of costs and benefits of their security choice. However, the results provide some of the first clear evidence that tax policy does significantly affect financing decisions. The analysis succeeds by controlling for confounding effects ignored in previous studies. However, tax effects seem important primarily for firms approaching a state of financial distress (positive loss carryforwards, or high tax shields when the bankruptcy predictor is high).

Another contribution of the paper is to adopt the incremental choice approach, which appears to be more statistically powerful than the usual debt/assets ratio analysis. Studying the numerouse specific financing decisions made by managers enables us to test a rich specification, and control for confounding effects that previous stndies have left unresolved. Nonetheless, the complexity of the financing choice problem suggests that to better understand the determinants of financing, it would be wise to look for narrower, more carefully controlled "experiments". 


\section{REFERENCES}

Altman, E. I. (1968) "Financial Ratios, Discriminant Analysis, and the Prediction of Corporate Bankruptcy," Journal of Finance, 23, 589-609.

Altman, E. I. (1984) "A Further Empirical Investigation of the Bankruptcy Cost Question," Journal of Finance, 39, 1067-1089.

Altman, E. I., R. G. Haldeman, and P. Narayanan (1977) "ZETA Analysis: An New Model to Identify Bankruptcy Risk of Corporations," Journal of Banking and Finance, 1, 29-54.

Altshuler, R. and A. J. Auerbach (1986) "The Significance of Tax Law Asymmetries: An Empirical Investigation," Working paper, University of Pennsylvania.

Ang, J. S. and D. R. Peterson (1986) "Optimal Debt Versus Debt Capacity: A Disequilibrium Model of Corporate Debt Behavior," in Research in Finance, vol. 6, ed. Chen, A. W.. Greenwich, CT: JAI Press.

Asquith, P., R. F. Bruner, and D W. Mullins (1987) "Merger Returns and the Form of Financing," Harvard Business School Working Paper.

Asquith, P. and D. W. Mullins (1986) "Equity Issues and Offering Dilution"," Journal of Financial Economics, 15, 61-89.

Auerbach, A. J. (1983) "Stockholder Tax Rates and Firm Attributes," Journal of Public Economics, 21, 107-27.

Auerbach, A. J. (1985) "Real Determinants of Corporate Leverage," in Corporate Capital Structures in the United States, ed. Friedman, B. M.. Chicago: University of Chicago Press.

Auerbach, A. J. and J. M. Poterba (1986) "Tax Loss Carryforivards and Corporate Tax Incentives," Working paper, Dept. of Economics, MIT.

Auerbach, A. J. and M. A. King (1985) "Taxation, Portfolio Choice and Debt Equity Ratios: A General Equilibrium Model," Quarterly Journal of Economics, 88, 587-609.

Bagnoli, M. and N. Khanna (1987) "Equilibrium with Debt and Equity Financing of New Projects: Why More Equity Financing Occurs When Stock Prices are High," Working Paper, Dept. of Economics, University of Michigan.

Bartholdy, J., G. Fisher, and J. Mintz (1985) "Some Theory of Taxation and Financial Policy with Application to Canadian Corporate Data," Paper presented at the Econometric Society Fifth World Congress, Cambridge, MA, August 17-24, 1985.

Baxter, N. D. and J. G. Cragg (1970) "Corporate Choice Among Long-Term Financing Instruments," Review of Economics and Statistics, 52, 225-35.

Ben-Akiva, M. and S. R. Lerman (1985) Discrete Choice Analysis: Theory and Application to Travel Demand. Carnbridge, MA: MIT Press.

Bradley, M., G. A. Jarrell, and E. H. Kim (1984) "On the Existence of an Optimal Capital Structure: Theory and Evidence," Journal of Finance, 39, 857-878.

Brealey, R. and S. C. Myers (1984) Principles of Corporate Finance. New York: McGraw-Hill.

Constantinides, G. M. and B. Grundy (1986) "Optimal Investment with Stock Repurchase and Financing as Signals," Working paper, University of Chicago.

DeAngelo, H. and R. W. Masulis (1980) "Optimal Capital Structure Under Corporate and Personal Taxation," Journal of Financial Economics, 8, 3-29. 
Dierkens, N. (1986) "Equity Issues and Asymmetric Information," Draft, Sloan School of Management, MIT.

Donaldson, G. (1969) Strategy for Financial Mobility. Boston, MA: Harvard Business School.

Donaldson, G. (1984) Managing Corporate Wealth: The Operation of A Comprehensive Financial Goals System. New York: Praeger.

Gale, D. and M. Hellwig (1985) "Incentive-Compatible Debt Contracts: The One-Period Problem," Review of Economic Studies, 52, 647-64.

Gordon, R. (1985) "Comment," in Corporate Capital Structures in the United States, ed. Friedman, B. M.. Chicago: University of Chicago Press.

Healy, P. M. and K. Palepu (1986) "Corporate Financial Decisions and Future Earnings Performance: The Case of Initiating Dividends," Preliminary draft, Sloan School of Management, MIT.

Hess, A. C. and P. A. Frost (1982) "Tests for Price Effects of New Issues of Seasoned Securities," Journal of Finance, 36, 11-25.

Jensen, M. C. (1986) "Agency Costs of Free Cash Flow, Corporate Finance, and Takeovers," American Economic Review, 76, 323-329.

Jensen, M. C. and W. H. Meckling (1976) "Theory of the Firm: Managerial Behavior, Agency Costs and Ownership Structure," Journal of Financial Economics, 3. 305-60.

Leland, H. E. and D. H. Pyle (1977) "Informational Asymmetries, Financial Structure and Financial Intermediation," Journal of Finance, 32, 371-387.

Long, M. S. and I. B. Malitz (1985) "Investment Patterns and Financial Leverage," in Corporate Capital Structures in the United States, ed. Friedman, B. M.. Chicago: University of Chicago Press.

MacKie-Mason, J. K. (1986a) “Long-Term Contracts and Sequential Economic Decisions,” Chapter 2, unpublished Ph.D. dissertation, Dept. of Economics, MIT.

MacKie-Mason, J. K. (1986b) "Taxes, Information and Corporate Financing Decisions," Chapter 3, unpublished Ph.D. dissertation, Dept. of Economics, MIT.

Marsh, P. R. (1979) "Equity Rights Issues and the Efficiency of the U.K. Stock Market," Journal of Finance, 34, 839-62.

Marsh, P. R. (1982) "The Choice Between Equity and Debt: An Empirical Study," Journal of Finance, 37, 121-144.

Martin, J. D. and D. F. Scott (1974) "A Discriminant Analysis of the Corporate Debt-Equity Decision," Financial Management, Winter, 71-79.

McFadden, D. (1974) "Conditional Logit Analysis of Qualitative Choice Behavior, ${ }^{n}$ in Frontiers in Econometrics, ed. Zarembka, P.. New York: Academic Press.

McFadden, D. (1981) "Econometric Models of Probabilistic Choice," in Structural Analysis of Discrete Data with Econometric Applications, ed. Manski, C. F. and D. McFadden. Cambridge, MA: MIT Press.

Miller, M. H. (1977) "Debt and Taxes," Journal of Finance, 32, 261-275.

Miller, M. H. and Modigliani, F. (1963) "Corporate Income Taxes and the Cost of Capital: A Correction," American Economic Review, 53, 433-43.

Miller, M. H. and M. Scholes (1982) "Dividends and Taxes: Some Empirical Evidence," Journal of Political Economy, 90, 1118-1141. 
Modigliani, F. and M. H. Miller (1958) "The Cost of Capital, Corporation Finance, and the Theory of Investment," American Economic Review, 48, 261-97.

Myers, S. C. (1977) "Determinants of Corporate Borrowing," Journal of Financial Economics, 5, $147-175$.

Myers, S. C. (1984) "The Capital Structure Puzzle," Journal of Finance, 39, 572-592.

Myers, S. C. and N. S. Majluf (1984) "Corporate Financing and Investment Decisions When Firms have Information that Investors Do Not Have," Journal of Financial Economics, 13, 187-221.

Poterba, J. M. (1986) "Taxation and Corporate Capital Structure," Comments prepared for the IV John Deutsch Roundtable of Economic Policy, The Impact of Taxation on Business Activity, Ot tawa, November 11-13, 1985.

Ross, S. A. (1985) "Debt and Taxes and Uncertainty," Journal of Finance, 40, 637-656.

Scholes, M. S. and M. A. Wolfson (1987) "Issues in the Theory of Optimal Capital Structure," in Frontiers of Modern Finance, ed. Bhattacharya, S. and G. Constantinides. : Rowman and Littlefield.

Stiglitz, J. E. and A. Weiss (1981) "Credit Rationing in Markets with Imperfect Information," American Economic Review, 71, 393-410.

Taggart, R. (197T) "A Model of Corporate Financing Decisions," Journal of Finance. 32, 1467-84.

Taub, A. (1975) "The Determinants of the Firm's Capital Structure," Review of Economics and Statistics, 57, 410-416.

Titman, S. (1984) "The Effect of Capital Structure on a Firm's Liquidation Decision," Journal of Financial Economics, 13, 137-152.

Watts, R. L. and J. L. Zimmerman (1986) Positive Accounting Theory. Englewood Cliffs, NJ: Prentice-Hall.

Williamson, S. (1981) “The Moral Hazard Theory of Corporate Financial Structure: An Empirical Test," Unpublished Ph.D. dissertation, Sloan School of Management, MIT.

Williamson, S. D. (1987) "Costly Monitoring, Loan Contracts, and Equilibrium Credit Rationing," Quarterly Journal of Economics, 102, 135-146. 


\section{TABLE 1}

Summary of Bypothesized Effects

(Change in Probability of Choosing Debt)

\begin{tabular}{|c|ccc|}
\hline Variable & Tax Bypothesis & $\begin{array}{c}\text { Financial Distress } \\
\text { (Moral Hazard) }\end{array}$ & Signaling \\
\hline Tax loss carryforwards & - & & \\
Investment tax credit & - & & \\
Deprec., Deferred taxes & - & & \\
Taxes paid & + & - & + \\
Clientele tax rate & - & - & \\
Research \& Development & - & - & \\
Advertising & - & - & \\
Unlevered "Beta" & & - & + \\
Unlevered "Sigma" & & - & \\
Earnings variance, Type A & & + & \\
Earnings variance, Type B & & + & + \\
Fraction assets in plant & & + & 0 \\
(Free) Cash flow & & - & 0 \\
Dilution & & - & - \\
Debt/Assets & & & + \\
Current D/A - Long-run D/A & & & \\
Change in stock price & & & \\
\hline
\end{tabular}




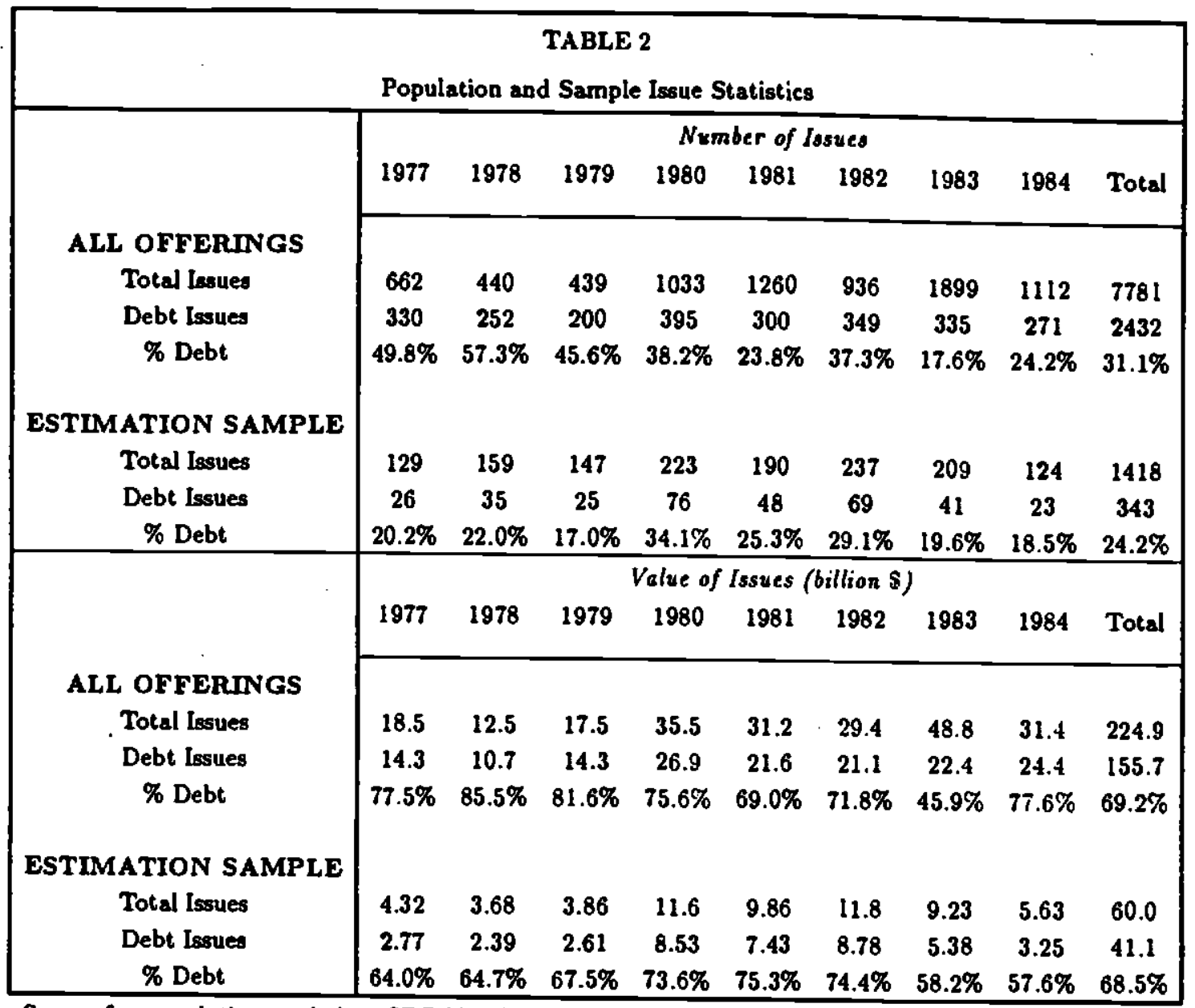

Source for population statisties: SEC Monthly Statistical Review

"All Offerings" includes only primary public offerings of bonds, convertible bonds, preferred stock, convertible preferred and common stock.

Population and estimation sample exclude state-regulated utilities and finance companies.

1977 population statistics are estimated by applying the overall ratio of public to private

offerings to the non-utility, non-finance totals 


\begin{tabular}{|c|c|c|}
\hline \multicolumn{3}{|c|}{$\begin{array}{c}\text { TABLE } 3 \\
\text { Descriptive Statistics } \\
\text { (1418 observations) }\end{array}$} \\
\hline Variable & Mean & Std. Dev. \\
\hline Debt/Equity Choice & 0.242 & 0.183 \\
\hline Tax loss carryforwards & 0.0140 & 0.123 \\
\hline Investment tax credits & 0.00494 & 0.00618 \\
\hline ITC / ZPROB & 0.00274 & 0.00574 \\
\hline Depreciation & 0.0430 & 0.0471 \\
\hline Deferred taxes* & 0.00945 & 0.0196 \\
\hline Current taxes paid* & 0.0321 & $0.036 a$ \\
\hline Clientele tax rate & 0.347 & 2.07 \\
\hline Research \& development & 0.0158 & 0.226 \\
\hline Advertising & 0.0142 & 0.0244 \\
\hline Unlevered "beta" & 0.560 & 0.417 \\
\hline Unlevered "sigma" & 0.0160 & 0.0407 \\
\hline Earnings variance, Type A & 0.0447 & 0.0435 \\
\hline VEARNA / ZPROB & 0.0204 & 0.0265 \\
\hline Earnings variance, Type B & 0.551 & 2.37 \\
\hline Fraction plant & 0.508 & 0.212 \\
\hline 1 / ZPROB & 0.451 & 0.274 \\
\hline Cash flow & 0.103 & 0.0776 \\
\hline Cash flow deficit & -0.0359 & 0.0684 \\
\hline Current debt/assets & 0.229 & 0.131 \\
\hline Current D/A - Long-run D/A & 0.00220 & 0.0902 \\
\hline Relative issue size & 0.183 & 0.456 \\
\hline Change in stock price & 0.127 & 0.468 \\
\hline Net Assets & 0.0924 & 0.309 \\
\hline Regulated firm & 0.0451 & 0.208 \\
\hline
\end{tabular}

Variables are reported as scaled in the analysis. See Appendix for details.

- Indicates statistics based on 1409 observations. 


\begin{tabular}{|c|c|c|}
\hline \multicolumn{3}{|c|}{$\begin{array}{c}\text { TABLE } 4 \\
\text { Determinants of Debt-Equity Choice } \\
\text { (Choice }=1 \text { if debt, } 0 \text { if equity) }\end{array}$} \\
\hline Variable & (1) & $(2)^{* * *}$ \\
\hline Constant & $\begin{array}{l}-1.69 \\
(4.99)\end{array}$ & $\begin{array}{l}-2.04 \\
(4.20)\end{array}$ \\
\hline $\begin{array}{c}\text { Tax Loss } \\
\text { Carryforwards }\end{array}$ & $\begin{array}{l}-2.73 \\
(2.03)\end{array}$ & $\begin{array}{l}-2.50 \\
(1.62)\end{array}$ \\
\hline $\begin{array}{l}\text { Investment } \\
\text { Tax Credit }\end{array}$ & $\begin{array}{c}75.3 \\
(2.72)\end{array}$ & $\begin{array}{c}72.4 \\
(2.58)\end{array}$ \\
\hline ITC/ZPROB & $\begin{array}{l}-106.7 \\
(2.60)\end{array}$ & $\begin{array}{c}-104 \\
(2.45)\end{array}$ \\
\hline $\begin{array}{l}\text { Clientele } \\
\text { Tax Rate }\end{array}$ & $\begin{array}{l}-0.0190 \\
(0.583)\end{array}$ & \\
\hline $\begin{array}{l}\text { Research and } \\
\text { Development }\end{array}$ & $\begin{array}{c}4.35 \\
(1.63)\end{array}$ & $\begin{array}{c}9.92 \\
(2.78)\end{array}$ \\
\hline Advertising & $\begin{array}{c}5.36 \\
(2.76)\end{array}$ & $\begin{array}{c}7.23 \\
(2.91)\end{array}$ \\
\hline Beta & $\begin{array}{c}-0.196 \\
(1.073)\end{array}$ & \\
\hline Sigma & $\begin{array}{l}-2.40 \\
(1.18)\end{array}$ & \\
\hline $\begin{array}{c}\text { Earnings Variance } \\
\text { (Type A) }\end{array}$ & $\begin{array}{l}-10.6 \\
(2.58)\end{array}$ & $\begin{array}{l}-13.4 \\
(3.61)\end{array}$ \\
\hline VEARNA/ZPROB & $\begin{array}{c}18.4 \\
(2.98)\end{array}$ & $\begin{array}{c}21.0 \\
(4.00)\end{array}$ \\
\hline $\begin{array}{l}\text { Earnings Variance } \\
\text { (Type B) }\end{array}$ & $\begin{array}{r}-0.825 \\
(4.21)\end{array}$ & $\begin{array}{r}-0.743 \\
(3.57)\end{array}$ \\
\hline $\begin{array}{l}\text { Fraction of assets } \\
\text { in plant \& equip }\end{array}$ & $\begin{array}{c}1.90 \\
(6.00)\end{array}$ & $\begin{array}{c}1.87 \\
(5.00)\end{array}$ \\
\hline
\end{tabular}




\begin{tabular}{|c|c|c|}
\hline \multicolumn{3}{|c|}{$\begin{array}{l}\text { TABLE } 4 \\
\text { Continzed }\end{array}$} \\
\hline Variable & (1) & $(2)^{* * * *}$ \\
\hline Cash Deficit & $\begin{array}{c}0.338 \\
(0.268)\end{array}$ & $\begin{array}{l}-0.0415 \\
(0.0321)\end{array}$ \\
\hline 1/ZPROB & $\begin{array}{c}0.00281 \\
(0.00618)\end{array}$ & \\
\hline Debt/Assets & $\begin{array}{l}-1.07 \\
(2.06)\end{array}$ & $\begin{array}{r}-0.851 \\
(1.52)\end{array}$ \\
\hline$\Delta$ Debt/Assets & $\begin{array}{l}-1.52 \\
(2.13)\end{array}$ & $\begin{array}{l}-1.62 \\
(2.11)\end{array}$ \\
\hline $\begin{array}{c}\text { Relative Size } \\
\text { (Ownership Dilution) }\end{array}$ & $\begin{array}{l}3.80 \\
(22.3)\end{array}$ & $\begin{array}{c}3.74 \\
(19.8)\end{array}$ \\
\hline$\Delta$ Stock Price & $\begin{array}{r}-0.487 \\
(3.87)\end{array}$ & $\begin{array}{l}-0.447 \\
(3.52)\end{array}$ \\
\hline Net Assets & $\begin{array}{l}0.683 \\
(8.58)\end{array}$ & $\begin{array}{l}0.493 \\
(5.23)\end{array}$ \\
\hline Regulated & $\begin{array}{r}-0.905 \\
(3.74)\end{array}$ & $\begin{array}{l}-1.77 \\
(2.56)\end{array}$ \\
\hline 1978 & -0.354 & -0.341 \\
\hline 1979 & $-0.431^{*}$ & -0.399 \\
\hline 1980 & 0.113 & 0.179 \\
\hline 1981 & -0.00113 & -0.00489 \\
\hline 1982 & -0.192 & -0.141 \\
\hline 1983 & $-0.470^{m *}$ & $-0.448^{* *}$ \\
\hline 1984 & $-0.525 * *$ & $-0.486^{* *}$ \\
\hline $\ln \mathcal{L}$ & -511.6 & -492.3 \\
\hline$M-\rho^{2}$ & 0.348 & 0.373 \\
\hline$\rho^{2}$ & 0.480 & 0.499 \\
\hline $\bar{p}^{2}$ & 0.451 & 0.459 \\
\hline \% Right Debt & $73.2 \%$ & $69.1 \%$ \\
\hline \% Right Equity & $90.1 \%$ & $91.1 \%$ \\
\hline \% Right Total & $86.0 \%$ & $85.8 \%$ \\
\hline
\end{tabular}

1418 observations. Asymptotic t-statistics in parentheses.

- Indicates year dummy significant at $10 \%$ level.

* Indicates year dummy significant at $5 \%$ level.

-* This specification included 16 industry dummy variables. See Table 5. 


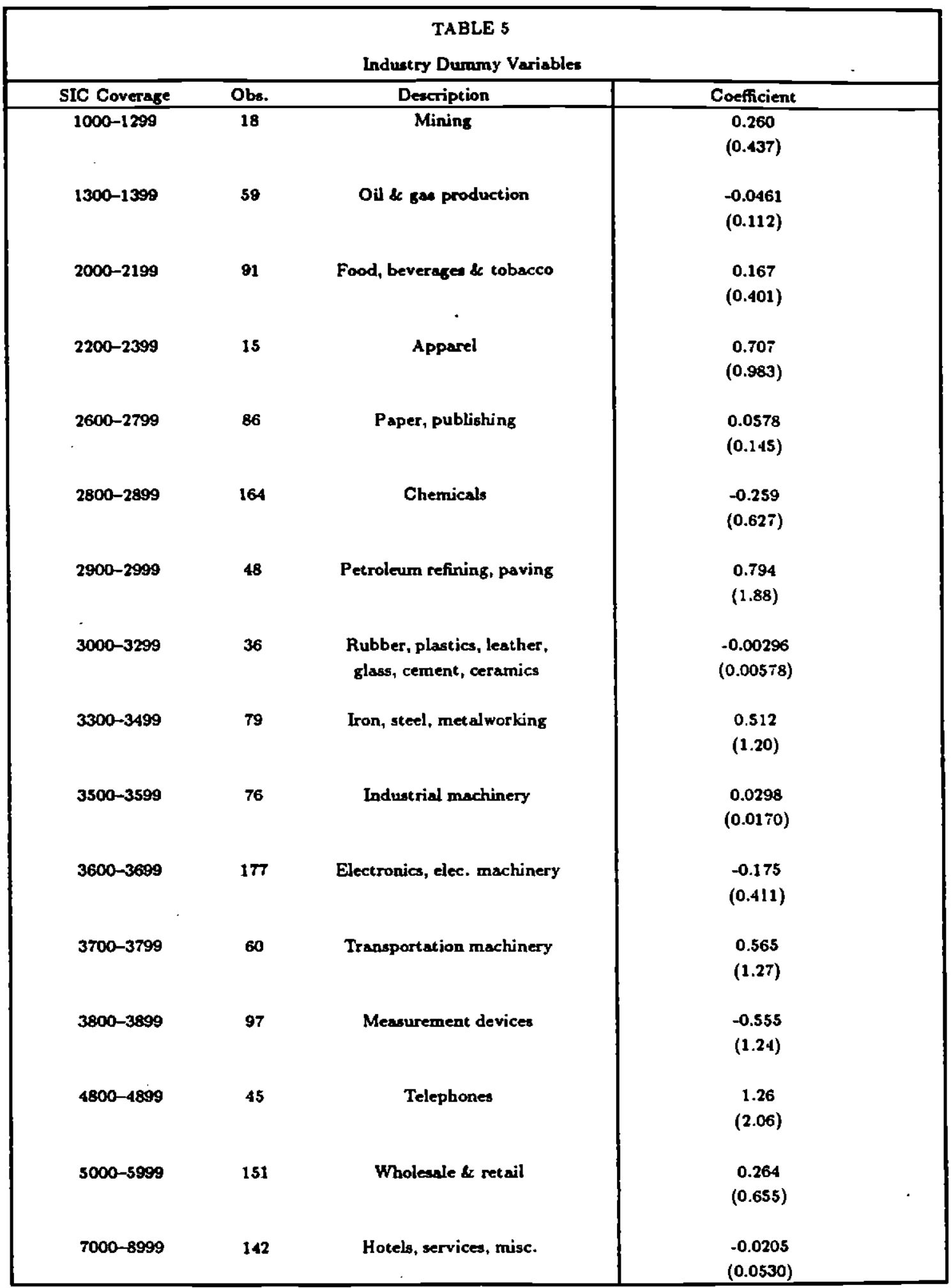

Results are from specification reported in Table 4, column 6.

Public utilities (SIC 4900-4999) and Financial \&. Real Estate services (SIC 6000-6999)

are excluded from the estimation sample (1017 and 268 observations, respectively.) 
TABLE 6

Tax Effects Without Interaction

(Chaice $=I$ if debt, 0 if equity)

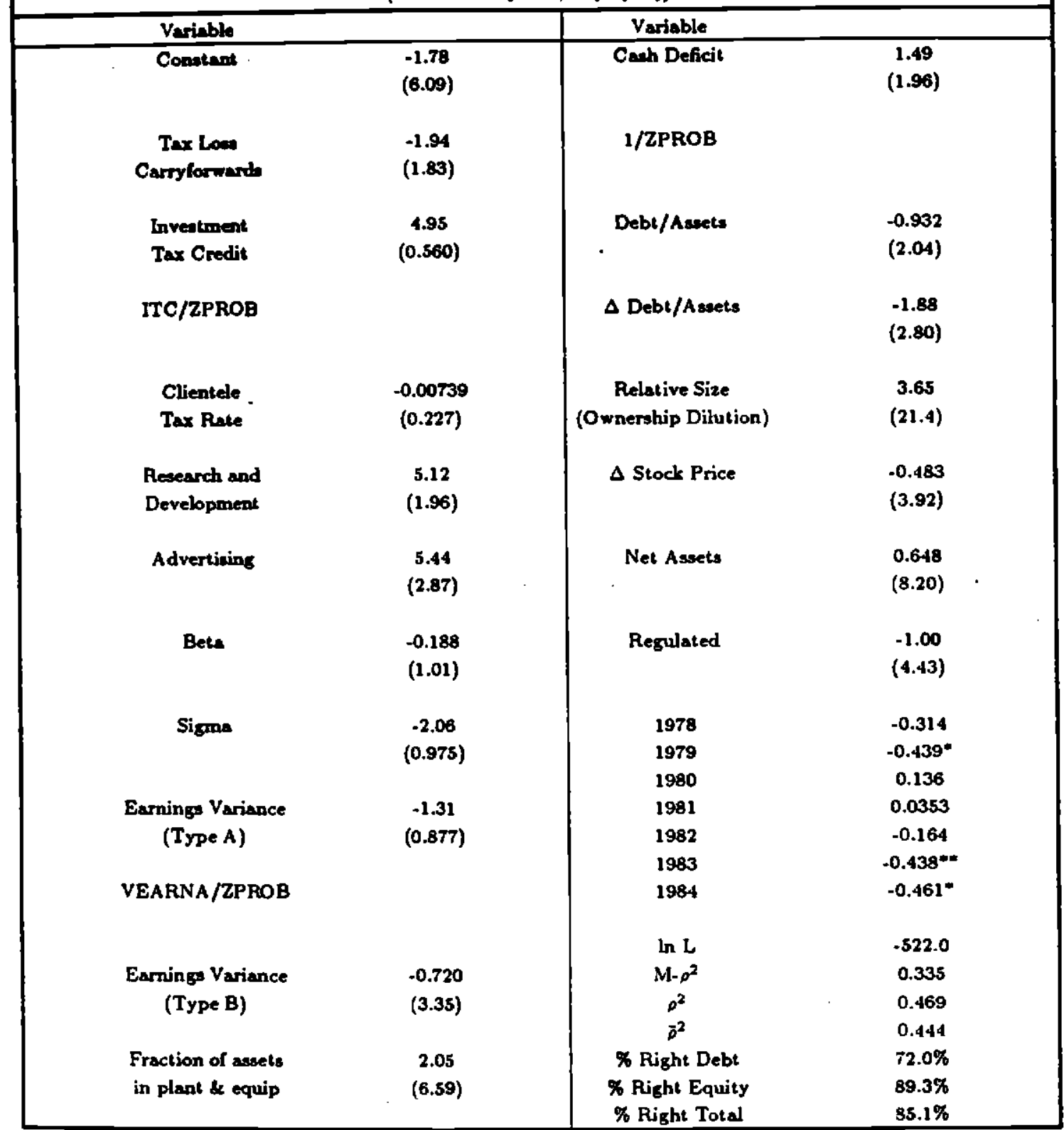

1418 observations. Asymptotic t-Btatistics in parentheses.

- Indicates year dummy significant at $10 \%$ level.

- Indicates year dummy significant at $5 \%$ level. 
TABLE 7

Specification Analysis of Debt-Equity Choice

(Choice $=l$ if debs, 0 if equity)

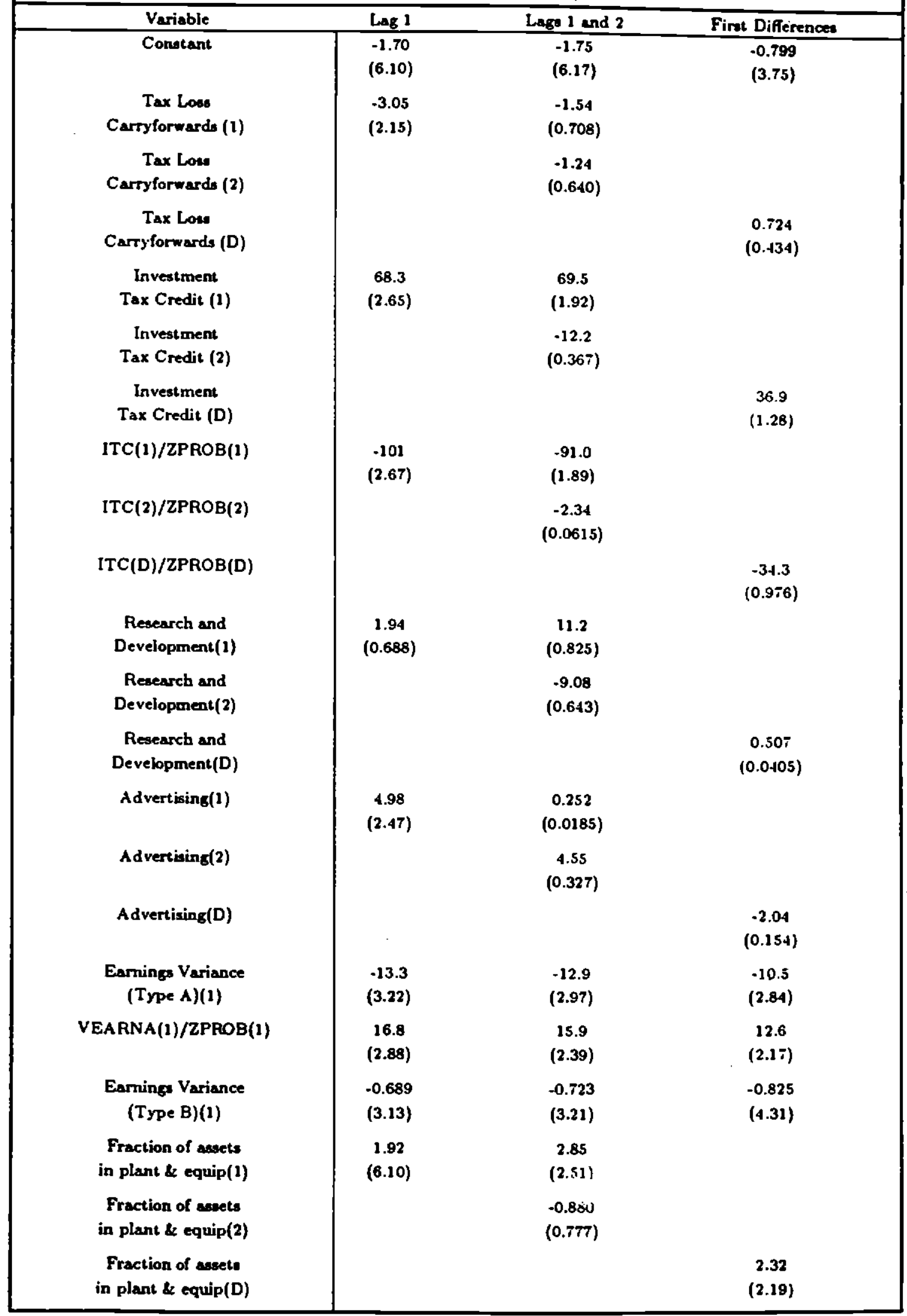

Continued 


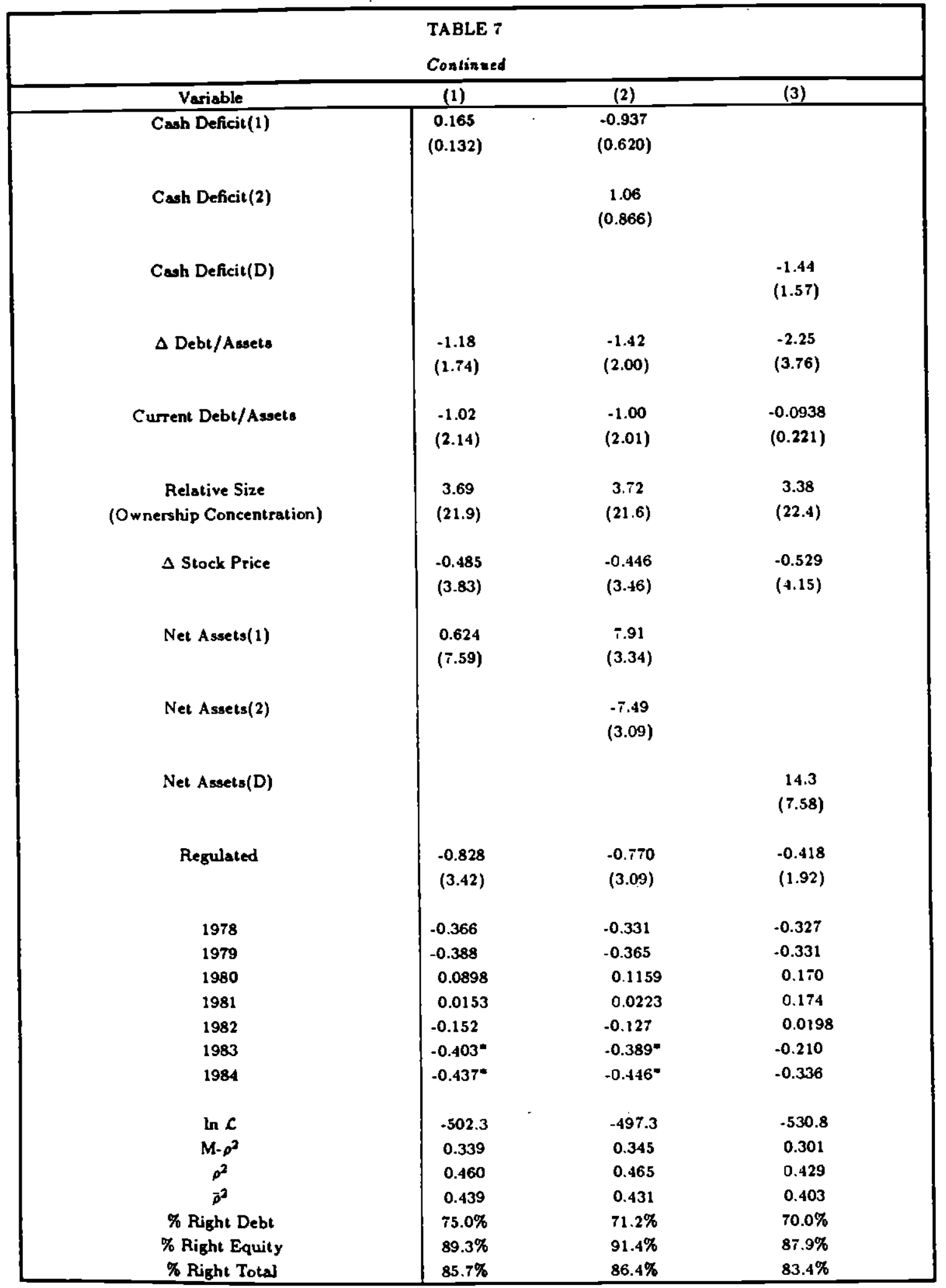

1341 observations. Asymptotic t-statistics in parentheses.

- Indicates year durnmy aignificant at $10 \%$ level.

- Indicatea year durmmy aignificant at $5 \%$ level. 
TABLE 8

Predictions For Hold-Out Sample

of "Unit" Offering Registrations

Individual Security Predictions

$(N=61$. Actual no. debt $=$ 10. Prediction cutoff $=0.97)$

\% Right Predictions

Debt

$85 \%$

Equity

$95 \%$

Total

$89 \%$

\section{Combined Security Predictions \\ ( $N=35$. See text for definitions)}

Debt fraction of issue value

Mean

$\underline{\text { Actual }}$

0.859

Predicted

Standard deviation

0.275

0.800

0.351

Spearman rank correlation coef.

0.407 


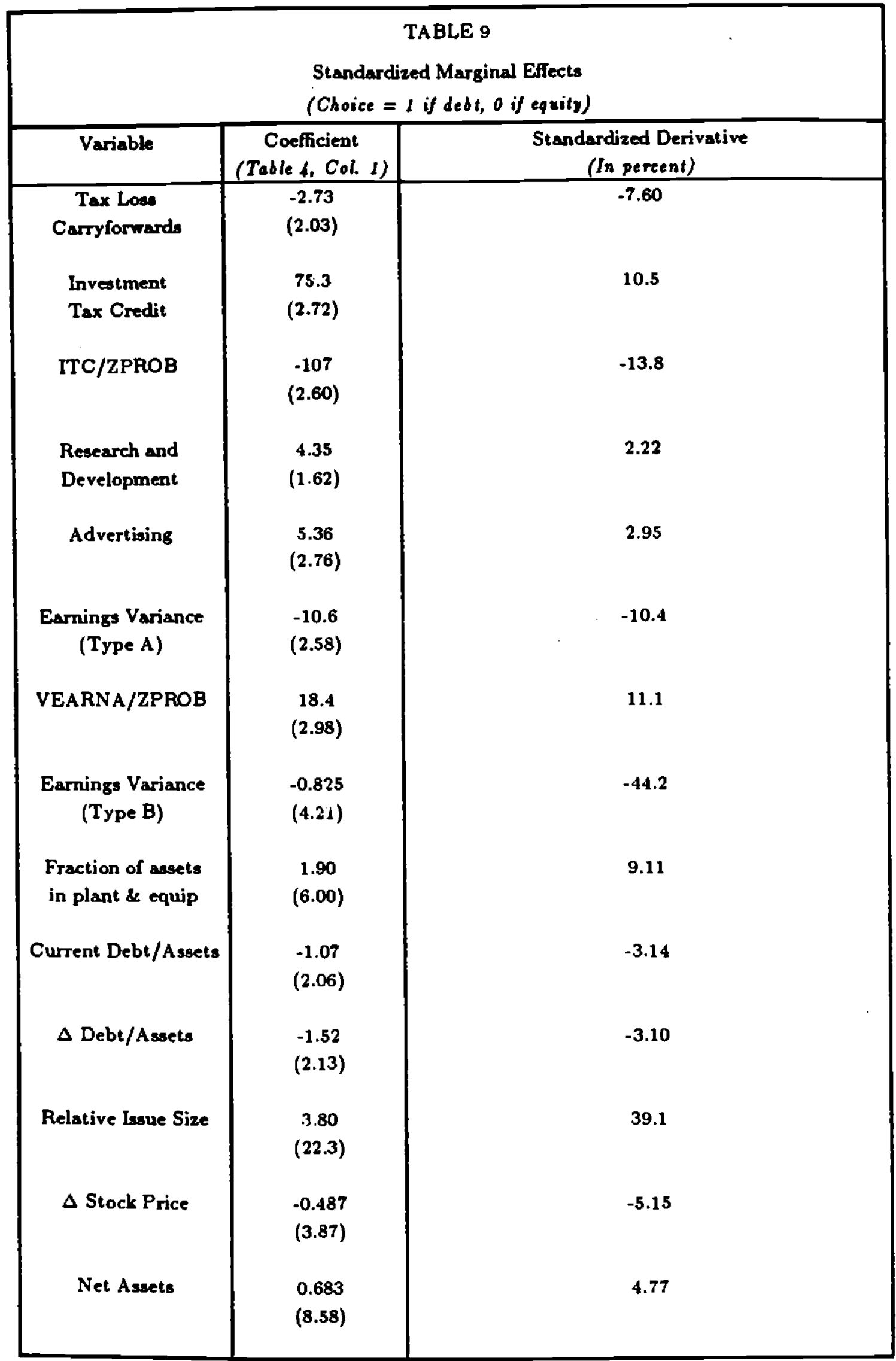

Asymptotic t-statistic in parentheses.

The standardized derivative is calculated as the change in the mean probability of issuing debt given a one standard deviation change in the variable ( $\bar{x}$ is mean of $x$ matrix).

std. deriv. for $x_{j}=\left[\frac{\partial \Phi\left(\bar{x}^{\prime} \beta\right)}{\partial x} \cdot \sigma_{j}\right] / \Phi\left(x^{\prime} \beta\right)$ 


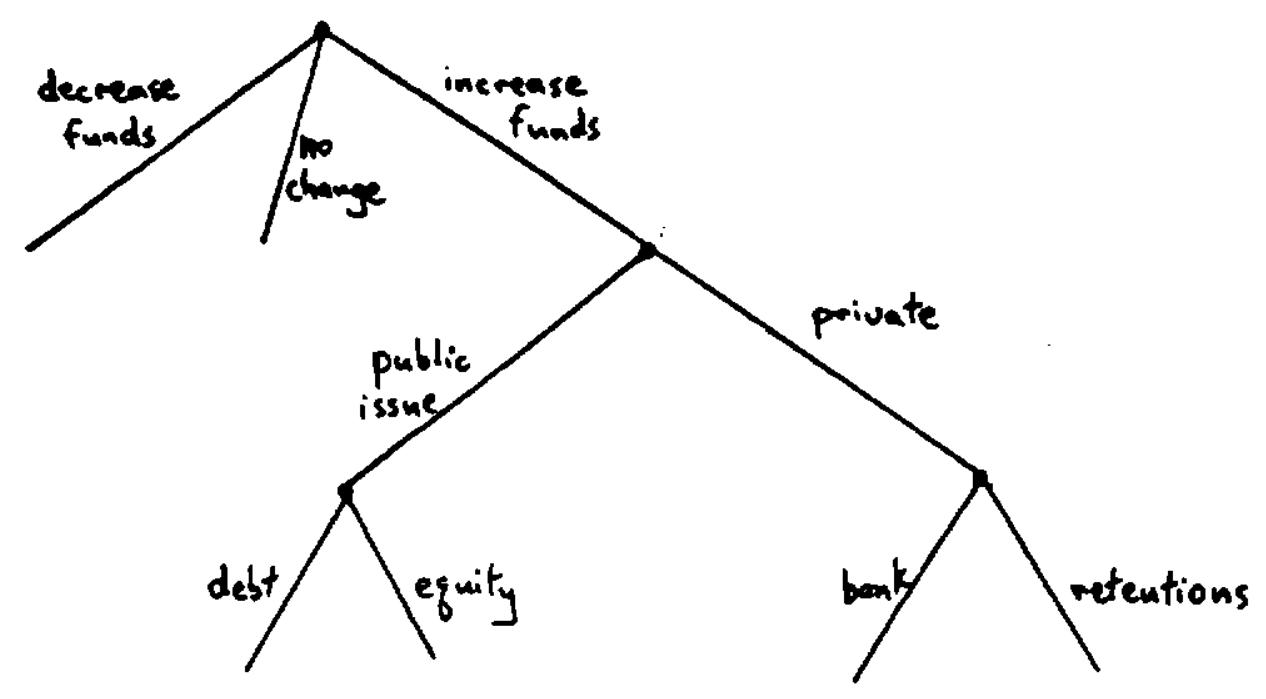

Figure 1.

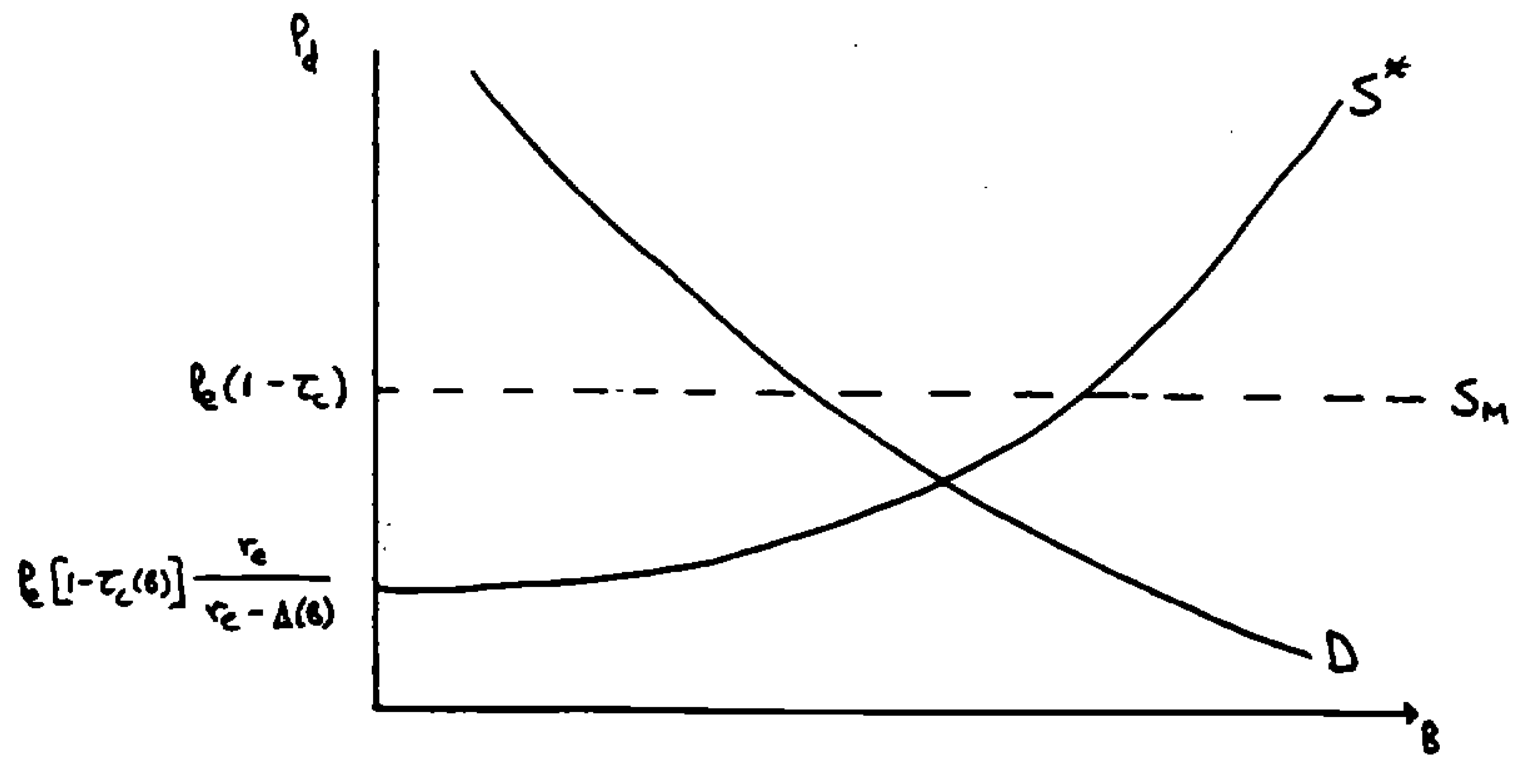

Figure 2. 


\section{APPENDIX}

\section{Dete Definitions}

For each firm in the sample, we estimated a variant of the "market model" for stock price returns. The model has been previously estimated by Auerbach [1983], based on theoretical work by Auerbach and King [1985] and Brennan [1970]. We estimated

$$
g_{1}=\alpha_{0}+\alpha_{1} d_{1}+\alpha_{2} m_{1}+\alpha_{3} r_{t}
$$

where $g_{1}$ is the 1-day capital gain in stock price, $d_{t}$ the dividend yield on date $t$ (calculated on ex-dividend days), $m_{1}$ the 1-day return on the equally-weighted index of all NYSE and AMEX stocks, and $r_{t}$ the return on government $T$-bills during the week containing day $t$. Daily data were obtained from the CRSP tapes. Use of daily data avoids confounding of tax effects with the information effects associated with dividend announcements; Miller and Scholes [1982] criticize earlier work for using monthly dividend returns. There is no reason to believe that the coefficients on (A.1) will be unvarying for a given firm over time; since many firms appear more than once in the sample, we estimated (A.1) on the most recent three years of daily data preceding the filing date of the registration statement for each registration in the sample.

The model is a standard CAPM except that it assumes individual investors have differing marginal tax rates. If taxes on dividends were zero, then the stock price should change one-for-one with dividend payouts on ex-days, so $\alpha_{1}$ would be -1 . The estimated $\dot{\alpha}_{1}$ is thus an estimate of an aggregated marginal tax rate $\left(\alpha_{1}=r_{c}-1\right)$ for the clientele of investors holding the firm's stock. The estimated $\hat{\alpha}_{2}$ is analogous to the usual "beta" of a market model regression. Details of the estimates can be found in MacKie-Mason [1986b].

In addition to "beta" and the clientele tax rate, we use the standard errors of regression ("sigma") as an indicator of firm-specific, diversifiable risk.

The COMPUSTAT tape provides financial statement data on several thousand large or otherwise "important" firms. All dollar-denominated variables were deflated to constant (1982) dollars, using the GNP deflator for gross private domestic investment. The definitions in the paper follow the COMPUSTAT definitions, unless otherwise noted.

We use book values of firm assets and liabilities. Auerbach [1985] and others attempt to approximate market values, but the results have usually indicated that book debt is just as appropriate as a determinant of financial decisions. Myers [1977, 1984] suggests that managers may rely on book measures because book value represents the fixed, or sunk value of firm assets. Market values include the value of intangible assets and future discretionary investments, which are predicted to reduce the firm's debt capacity.

We list below the definitions of variables used in the analysis.

Market value of equity $=$ shares outstanding $\times$ stock price (as of $12 / 31)$

Tax loss carryforward = book tax loss carryforward / market value of equity. ${ }^{1}$

Investment tax credit $=$ investment tax credits / net sales.

ZPROB: Altman's [1968] ZPROB included the ratio of market equity to book debt. We have excluded that term since we are studying precisely capital structure, and enter the debt ratio directly into the analysis.

$$
Z P R O B=3.3 \frac{\mathrm{EBIT}}{\text { total assets }}+1.0 \frac{\text { sales }}{\text { total assets }}+1.4 \frac{\text { retained earnings }}{\text { total assets }}+1.2 \frac{\text { working capital }}{\text { total assets }}
$$

where EBIT is earnings before interest and taxes.

Research and development $=\mathrm{R} \& \mathrm{D} /$ net sales. If $\mathrm{R} \& \mathrm{D}$ is missing, the variable is coded as zero. A specification test indicated no significant bias from this recoding.

1 We scale by market equity because TLCF is ill-behaved when scaled by net sales; TLCF is generally high when sales are low, distorting the allempt to get a acale-lice measure. 
Advertising $=$ advertising expenditures / net sales. Recoding was done as for RSD.

$E B I D T=$ earnings before interest, depreciation and taxes.

Earnings variance, Type $A=$ standard deviation of $\left(E B I D T_{t}-E B I D T_{t-1}\right)$, divided by the mean of total assets, for 10 years prior to registration (at least six years if data are missing).

Earnings veriance, $T_{y p e} B=$ standard deviation of $\left[\left(E B I D T_{t}-E B I D T_{t-1}\right) /\left|E B I D T_{t-1}\right|\right]$, for 10 years prior to registration (at least six years if data are missing).

Fraction of assets in plant $\&$ equipment $=$ (plant - accumulated depreciation) $/$ (total assets - current liabilities).

Cesh deficit $=$ (capital expenditures + average dividends - (cash flow + capital expenditures $\times$ [total debt $/$ net assets])) / net sales, where average dividends is the mean of total dividend payments over the previous 10 years. See Auerbach [1985].

Current debt/assets ratio $=$ book long $\cdot$ term debt $/$ total assets.

$\Delta$ Debt/assets $=$ current debt/assets ratio - (mean of debt/assets ratio over previous 10 years) .

Dilution $=$ issue value / market value of equity.

$\Delta$ stock price $=($ end-of-year price in year previous to registration $)-($ end-of-year price two years previously $)$.

Net assets $=$ total assets - current payables.

Taxes paid $=$ (current payables two years ago $)+($ provision for income taxes one year ago) - (current deferred taxes one year ago) - (current payables one year ago).

Auerbach and Poterba [1986] suggest that the TLCF variable in COMPUSTAT may be inappropriate for studying U.S. tax policy, in part because book TLCF may include foreign carryforwards which are not applicable to U.S. taxable income. They created a revised data series on TLCF for the years 1981-1984; we followed their approach to revise the data for the other years in our sample. We re-estimated column 4 utilizing the revisions, with the resulting coefficient on TLCF negative but insignificant. We replaced TLCF wherever possible with revised data, and included a dummy variable to check for bias from splicing the two series. There appear to be problems in the construction of the revised data, since the revision requires searching the footnotes of a firm's 10-K. Correct TLCF data is unavailable for most observations, because firms are not required to report true tax TLCF. Also, the mean for TLCF actually rose (despite the expectation that foreign carryforwards were biasing book TLCF upwards), and the standard error grew substantially. We use book TLCF, acknowledging that it is an imperfect, but apparently informative measure of one tax shield.

Sample Selection

The initial source of data was the Registered Offerings Statistics (ROS) tape from the SEC. This file contains financial and other information reported for all public security registrations. The tape contained 68,316 registered offerings covering 1970-1984. Because this data source is not well-known, we describe our sample selection procedure in some detail.

Issues were dropped if: (1) the issuing firm is not on the COMPUSTAT tape; (2) the registration is for an initial public offering; (3) the registration is for a noncash transaction; (4) the issuing firm was not listed on the NYSE or AMEX; (5) the security was registered before January $1,197 \overline{7}$; (6) the security was not one of straight debt, convertible debt, preferred stock, convertible preferted, or common stock. 
Some of these restrictions are necessary to obtain stock market information and data on firm characteristics. Initial offerings were dropped because historical firm data are unavailable, and the IPO decision is likely to be fundamentally different from ongoing financing decisions. Noncasb offerings are mostly exchanges, conversions and other transaction types which are not obviously intended to raise new capital. Only the five major security types were retained because most of the theory is concerned only with broad distinctions among contingent claims. Pre-1977 issues were deleted because the SEC did not collect information on some relevant variables during $1970-1976$.

Registrations by foreign firms, registrations with warrants to purchasers ( $0.1 \%$ of the subsample), and registrations for rights offerings $(0.6 \%)$ were also dropped. The final selection dropped gas and electric utilities, financial services, and real estate firms, and firms for which required data was missing. ${ }^{2}$ We dropped the selected industries because their capital market interactions are known to be quite different than other firms, due to regulation or the financial nature of the business.

2 An extensive hand search of Moody's Industrial Manual and individual 10K reports recovered enough missing data to keep about 200 observations in the sample. 